\title{
Golden Share as a Tool of Corporate Strategic Management of the State
}

\author{
Tatyana A. Tchilimova \\ Ural State University of Economics \\ Ekaterinburg, Russia \\ tachil77@mail.ru
}

\author{
Anna I. Serebrennikova \\ Ural State University of Economics \\ Ekaterinburg, Russia
}

\author{
Irina A. Sofronova \\ Ural State University of Economics \\ Ekaterinburg, Russia
}

\begin{abstract}
For countries with transition economies, where the process of market transformation is a long-term task, the issues of strategic management of public property are urgent. In Russia, traditionally, as well as in the world practice, the importance of state property is associated with industries and sectors having an effect on the socio-economic situation in the country. The authors believe the optimal choice of strategic management tools to be of great importance in the development of corporate management. The paper deals with one of these tools, namely a golden share showing the reasons for using this tool and giving examples of applying it in different countries. The very concept of golden share is present in the laws of many countries though it is not well-defined. The authors give the definition of a golden share, its characteristics included. The historic and legal analysis of the Russian practice shows that this tool is used in the industries of strategic importance to ensure the defense and security of the state or influence the socio-economic stability in society. Finally, the authors comment on pros and cons of a golden share for the state, for the company and for its investors.
\end{abstract}

Keywords-a golden share; state property; corporate strategic management.

\section{INTRODUCTION}

Among the urgent tasks of improving corporate management in Russia, a special place is occupied by the development of corporate management in companies with state participation. There are several reasons for this:

- government's attempt to hold a major stake during the privatization of large companies,

- prevention of unbundling and deteriorating assessed value of business during privatization processes,

- planned transfer of a number of state-run companies (called state corporations) into a new legal form, etc.

\section{Problem Statement}

For us to realize the urgency of this issue, we will analyze the level of transfer of the Russian economy into state ownership. According to the Organization for Economic Cooperation and Development (hereinafter-OECD), the indicator of state control of the economy, consisting of five private indicators, amounted to almost 4.4 out of six possible in 2016. This is twice as large as the OECD average, and by 1.7 times higher than the OECD emerging markets average. As for the scale of state ownership, Russia surpasses both OECD countries (27 countries) and developing countries [4].

The importance of state ownership in the OECD countries, as well as in Russia, is attributed to the "strategic" nature of such industries as the military-industrial complex, gas and oil industries, power engineering, post, the main transport systems and a number of others. Today, in almost all OECD countries, the state is involved in some of the above sectors. For example, in such countries as the Czech Republic, Denmark, Finland, Italy and Norway, the state owns the postal system, railways, as well as holds the major stake in power engineering and air transport [4][5].

At the same time, the goals of the state as a property owner are still defined differently in different countries. In Sweden, the concept of policy in this area is formulated in the following way: "the main objective of the government is to create value for owners". In France, the task of the Agency of Public Property is "to take care of the interests of the state as a property owner ". In the UK, the main objective of corporate management is "to ensure that the government's equity ownership brings sustainable, positive results and eventually allows to cover the cost of capital within the framework of political, regulatory and consumer parameters set by the government, and through the effective and reasonable activities of the state as a shareholder" [6].

In terms of the development of forms of corporate management with the participation of the state, the choice of 
- when making a decision on the exclusion of a public joint-stock company from the list of strategic ones regardless of the number of shares owned by the state.

The special right of golden share is used from the moment of alienation from the state ownership of $75 \%$ of shares of the corresponding public joint-stock company.

In accordance with the Russian legislation a golden share has a number of characteristics, such as: this tool

- provides a set of corporate and administrative rights, i.e. it is not a kind of securities;

- has no nominal value;

- does not accrue dividends;

- cannot be replaced by shares of the public joint-stock company towards which the golden share is used;

- does not grant the right to part of the property at liquidation of the public joint-stock company;

- acts as a warrantor of protection of national and social interests of the state.

\section{RESEARCH ISSUES AND METHODS}

As for corporate management, the Russian Federation sets various objectives ranging from increasing profitability of the Federal budget through maximizing non-tax revenues to implementation of social programs.

To solve the problems facing the state as a property owner, the latter uses a fairly large set of management methods and tools, among which a special position is occupied by the golden share.

Historic and legal analysis of the concept of golden share allows us to draw a number of conclusions.

A golden share is a tool used to ensure a special state control over the activities of privatized joint-stock companies. For the first time the legal nature of this tool was specified by the Decree of the President of the Russian Federation of November,16 1992 No.1392 "On Measures for the Implementation of Industrial Policy in Privatization of State Enterprises", in which the golden share was considered as a security.

Nowadays using golden shares is regulated by Federal Law of December, 212001 No. 178-Ф3 (containing subsequent additions and amendments) "About Privatization of the State and Municipal Property". Clause 38 of this law defines a golden share as a special right for the Russian Federation and subjects of the Russian Federation to participate in management of public joint-stock companies, providing them with a significant amount of authority, including the right of veto when taking decisions at the general meeting of shareholders on a number of issues fundamental for the government.

The decision to use a special right can be made in two cases:

- when privatizing property complexes of unitary enterprises,

\section{FINDINGS}

To sum it up, it should be noted that the special right of a golden share is official by its nature, aiming at protecting public interests, not private ones. It is this approach that explains why this right is used only in a relatively small number of public joint stock companies: e.g. defense enterprises or enterprises of special Federal importance, as well as those excluded from the list of strategic joint-stock companies. The objective of golden shares is to protect the internal interests of the Russian Federation.

The practice of using golden shares in Russia began in the early 90 -es of the 20th century. From the beginning of 1993 to 2005 inclusive there were founded 1707 joint-stock companies with golden shares. They amounted to $6 \%$ of the total of jointstock companies of this period. 734 enterprises out of the above number accounted for the industrial sector (43\%). Since the cancellation of the golden share is not reflected in statistic observations, the annual figures do not indicate the real number of public joint-stock companies with golden shares. According to the Agency on Federal Property Management at the end of 2005 , there were already 259 public joint-stock companies, in which the state did not own shares, but the golden shares were used and maintained [7][8]. This negative trend is in line with the general trend of a decreasing state share in the overall structure of joint-stock ownership due to the inert continuation of the process of monetary privatization of state-owned enterprises.

According to the report by the Federal State Information and Analytical System " The Unified System of State Property Management" of August 1, 2016 the Register of Federal Property contains information on 1593 joint-stock companies in which the state has stock, including 72 companies where the special right of golden share for participation of the Russian Federation in the management of companies is used [7]. 
shares as a strategic tool used by the state in the system of corporate management.

\section{References}

[1] OECP Principles of Corporate Governance// OECP// G20/OER Publishing, Paris, 2015.p.41.

[2] Code of Corporate Management//Bulletin of the Bank of Russia, on April 18, 2014. No.40 (1518). p.15.

[3] Commission of the European Communities v French Republic http://curia/eu/int/eur-lex/lex/en/treaties/index.htm/

[4] The Organizations for Economic Cooperation and Development (OECD) - http://www.oecd.org/actual.html /

In spite of pitfalls to golden shares discussed in literature, they can give the company a number of advantages: small probability of bankruptcy, state orders, subsidies from the state budget, state guarantees. All these can attract investors and contractors to such enterprises.

For the state, a golden share acts as a guarantor of protecting national and social interests. With its help, the state can exercise control over the activities of socially significant corporations and regulate industries and sectors of the economy that are of sufficient importance for the development of the country. That is why it is necessary to consider golden
[5] National report on corporate management, 2108. http://interros.ru/upload/video/NSKU_2018.pdf. Companies: Comparative Law, European Law and Policy Aspects // European Banking and Financial Law Journal (EUREDIA). 2004. No. 1. p. 17.

[7] Federal State Information and Analytical System “ The Unified System of State Property Management” - https://portal.eskigov.ru/open this /

[8] Ministry of Economic Development of the Russian Federation http://economy.gov.ru/minec/activity/sections/govproperty/
[6] Grundmann S., Moslein F. Golden Shares - State Control in Privatised 